\title{
RESEARCH
}

Open Access

\section{HCV/HIV coinfection among people who inject drugs and enter opioid substitution treatment in Greece: prevalence and correlates}

\author{
Anastasios Fotiou ${ }^{1 *}$ (D) Eleftheria Kanavou ${ }^{1}$, Argyro Antaraki ${ }^{1}$, Clive Richardson², Manina Terzidou ${ }^{1}$, Anna Kokkevi ${ }^{3}$ \\ and Drug Related Infectious Diseases (DRID) Medical Doctors Group of OKANA ${ }^{4}$
}

\begin{abstract}
Background: HCV/HIV coinfection in people who inject drugs is a public health issue, which presents a variety of challenges to healthcare providers. The determinants of HCV/HIV coinfection in this population are nonetheless not well known. The aim of the present study is to identify the factors associated with HCV/HIV coinfection in people who inject drugs and enter drug-related treatment.

Methods: Linked serological and behavioral data were collected from people who entered 38 opioid substitution treatment clinics in central and southern Greece between January and December 2013. Three mutually exclusive groups were defined based on the presence of HCV and HIV antibodies. Group 1 clients had neither infection, Group 2 had HCV but not HIV, and Group 3 had HCV/HIV coinfection. Multinomial logistic regression analyses identified differences between groups according to socio-demographic, drug use and higher-risk behavioral characteristics.

Results: Our study population consisted of 580 people who injected drugs in the past 12 months (79.8\% males, with median age 36 years).79.4\% were HCV and $15.7 \%$ HIV infected. Of those with complete serological data in both HCV and HIV indicators, $20.4 \%$ were uninfected, $64.0 \%$ HCV monoinfected, and $14.9 \%$ HCV/HIV coinfected. HCV infection with or without HIV coinfection was positively associated with living alone or with a spouse/partner without children, prior incarceration, drug injecting histories of $\geq 10$ years, and syringe sharing in the past 12 months, and negatively associated with never having previously been tested for HCV. HCV/HIV coinfection, but not HCV infection alone, was positively associated with residence in urban areas (relative risk ratio [RRR] $=4.8,95 \%$ confidence interval [Cl]: 1.7-13.7, $p=0.004$ ) and averaging $>3$ injections a day in the past 30 days (RRR $=4.5,95 \%$ Cl: 1.6-12.8, $p=0.005)$, and negatively associated with using a condom in the last sexual intercourse.

Conclusions: People who inject drugs and live in urban areas and inject frequently have higher risk of coinfection. Findings highlight the need for scaling-up needle and syringe programs in inner city areas and promoting access of this population to screening and treatment, especially in prisons. The protective role of living with parents and children could inform the implementation of indicated interventions.
\end{abstract}

Keywords: Hepatitis C virus, Human immunodeficiency virus, HCV/HIV coinfection, People who inject drugs, PWID, Opioid substitution treatment, Risk factors, Greece

(Continued on next page)

\footnotetext{
* Correspondence: afotiou@ektepn.gr

${ }^{1}$ Epidemiology Unit, Greek Reitox Focal Point of the EMCDDA, University

Mental Health Research Institute, 2 Soranou tou Efesiou St., Athens 11527,

Greece

Full list of author information is available at the end of the article
} 
(Continued from previous page)

Abbreviations: AIDS, Acquired immunodeficiency syndrome; ART, Antiretroviral therapy; Cl, Confidence interval; EFTA, European Free Trade Association; EIA, Enzyme immunoassay; ELISA, Enzyme-linked immunosorbent assay; EMCDDA, European Monitoring Centre for Drugs and Drug Addiction; EU, European Union; HCV, Hepatitis C virus; HIV, Human immunodeficiency virus; NSP, Needle and syringe programs; OKANA, Greek Organization Against Drugs; OST, Opioid substitution treatment; PWID, People who inject drugs; RIBA, Recombinant immunoblot assay;

RNA, Ribonucleic acid; RRR, Relative risk ratio

\section{Background}

Intravenous drug use is responsible for the majority of new $\mathrm{HCV}$ infections and $\mathrm{HCV}$ is the most prevalent viral infection among people who inject drugs [1-3]. It is estimated that about $44 \%$ of current injection drug users in the countries of the European Union (EU) and the European Free Trade Association (EFTA) have HCV RNA [4]. HIV often co-occurs with $\mathrm{HCV}$ as both are transmitted through infected blood, mainly through injection drug use [1, 2, 5-7]. Chronic HCV infection is the most common comorbidity in HIV infected drug users, with the prevalence of HCV infection among HIV infected drug users reaching rates higher than $70 \%$ in several countries and regions in western $[1,8]$ and eastern Europe [1], Latin America and the Caribbean [1], and Asia $[1,7,8]$.

$\mathrm{HCV} / \mathrm{HIV}$ coinfection in drug users is a growing public health concern. While HCV infection in itself causes substantial morbidity and mortality [9-11], patients with HIV co-infection have much higher odds to accelerate $\mathrm{HCV}$ infection to endstage liver disease than those infected with hepatitis $C$ alone [8, 12-14]. Coinfection with HIV also contributes to development or acceleration of cardiovascular disease, neurocognitive impairment, insulin resistance, and renal insufficiency [15].

$\mathrm{HCV} / \mathrm{HIV}$ coinfection presents a variety of challenges to healthcare providers [16-19]. HIV/HCV coinfected drug users have significantly higher risk of having poorer physical and mental health and use more healthcare services compared to those infected with HIV only [20, 21]. Co-occurring HCV decreases the benefits of antiretroviral therapy (ART) [10], while drug addiction complicates treatment regimens and leads to treatment-related adverse events [22]. HIV/HCV coinfected people with long injection histories are significantly less likely to achieve virologic suppression and CD4 cell count recovery, and have a higher risk of death [16, 23]. Finally, coinfected drug users do not have equitable and universal access to HIV/AIDS and HCV treatment [16, 24, 25]. Barriers to treatment may be aggravated by the stigma associated with drug users with comorbidities, and preconceptions shared among healthcare providers who assume low compliance, high risk of reinfection, and poor response to $\operatorname{ART}[26,27]$.
Given the evidence suggesting higher morbidity and mortality among coinfected drug users, there is a need to document the prevalence of coinfection in this population and to identify factors that put $\mathrm{HCV}$ uninfected or HCV monoinfected populations at risk for HIV infection. The rather limited evidence available points to the independent role of various behavioral and sociodemographic factors. Behavioral factors include: longer periods of injection drug use [5, 28-33]; receptive sharing of injection equipment [5, 32-36]; frequent injection [5, 31-33, 35]; present or past incarceration [29, 35, 37, 38]; drug use during incarceration [39]; and high risk sexual behavior [30]. Socio-demographic factors include: residence in metropolitan areas where injection drug use takes place [5]; female gender [5]; older age [5, 39]; ethnicity (in northern American studies, e.g., Hispanic in [29] and Canadian aboriginal in [5]); and lower education [28].

In Greece an estimated 2.0-2.6 people per 1000 people aged 15-64 years are heroin drug users [40, 41]. Problems with heroin or other opioids are reported by the majority (69\%) of people entering treatment [41]. In 2014, the estimated prevalence of antibodies to HCV among injection drugs users entering all types of drugrelated treatment was $71 \%$ overall, and $80 \%$ among first-ever treatment entries [41]. Until 2011, HIV among injection drug users never exceeded $3 \%$ of new HIV diagnoses reported annually [41-43]. In 2011, the number of new HIV diagnoses increased sharply, rising from 5.5 in 2010 to 10.7 per 100,000 in 2012 [44, 45]. These increases were observed only in Athens and were driven by injecting drug use [42, 44, 45]. Studies conducted in community samples of injection drug users in Athens suggested an HIV prevalence of up to about $15 \%$ [46].

In Greece, little is known about the profiles of injection drugs users characterized by different infection statuses for HCV and HIV (e.g., [43, 47, 48]), while no published study is known to the authors to have explored the factors associated with coinfection. The present study attempts to fill this gap and aims at identifying injection drug users in the country who are at the greatest infection risk based on their sociodemographic, drug use and higher-risk behavioral characteristics. More specifically, drawing from existing knowledge, the study aims to differentiate drug users at risk of $\mathrm{HCV}$ 
monoinfection from those at risk of HCV/HIV coinfection so that policy makers and health care and harm reduction practitioners working close to this population could utilize findings to design appropriate prevention programs and help drug users with differing needs.

\section{Methods}

\section{Study population and process}

The study population consisted of all heroin or other opioid users who started treatment in outpatient opioid substitution treatment (OST) clinics of the Greek Organization Against Drugs (OKANA) in central and southern Greece in the period between January 1 and December 31, 2013 and had injected drugs in the 12 months preceding their entry $(n=580)$. Given the study aims, the inclusion criteria were dictated solely by the need to have data on a wide range of behavioral variables that could be used as explanatory variables and therefore allow for more meaningful analyses. During the data collection period (2013) only the OST outpatient clinics located in southern and central Greece had established a data collection system which included a wide range of behavioral variables. The 38 clinics from which the participants were recruited had similar organisational structure and employed common treatment protocols. They were located in the capital cities of 14 prefectures in 9 of the 13 administrative regions of the country (Attika, Peloponnese, Crete, Epirus, Thessaly, Western Greece, Central Greece, Ionian Islands, and the Southern Aegean region; representing about $73 \%$ of the total population in Greece). OST clinics and participants in the study formed about $70 \%$ of the total OST outpatient clinics in operation and $72 \%$ of the past 12 month injection drug users who entered OST in the country in 2013.

Serological and behavioral data, linked through an anonymised identification code, were collected in the clinics through a routine data collection system established by the Greek REITOX Focal Point of the European Monitoring Centre for Drugs and Drug Addiction (EMCDDA) (henceforth, Focal Point) since the end of the 1990s. Data collection was paper-based and involved all drug users starting treatment in the clinics. Upon entry, each person was tested for HCV and HIV antibodies and interviewed by health practitioners working in the respective clinic. Interviews were guided by the use of a standardised structured questionnaire. Serological testing was provided for by internal OST treatment protocols. No client-level refusals were reported (although there were questionnaires with incomplete serological data, attributed to reasons other than refusing to test or to report results). Completed questionnaires were subsequently sent to the Focal Point, where they were checked for incomplete data and inconsistencies.
The questionnaires were scanned and entered in the electronic database. A second round of (electronic) checks for data entry errors, excessive number of missing values, logical inconsistencies, and double-counting was conducted by an in-house statistician. The collection and management of the data at the Focal Point was approved by the Hellenic Data Protection Authority (Decision number: $2186,1 / 11 / 2001)$.

\section{Measures}

The outcome of interest was HCV and HIV infection status as a proxy of infection risk. Data were based on serological tests (blood samples). Antibodies to HCV, indicating $\mathrm{HCV}$ exposure, were detected by enzyme-linked immunosorbent assay (ELISA), with recombinant immunoblot assay (RIBA) or enzyme immunoassay (EIA) confirmation (in all cases, commercial kits were used). Antibodies to HIV, documenting HIV infection, were detected by ELISA, with Western Blot immunoassay for HIV-1/2 confirmation. The presence of HCV antibodies and documented HIV infection indicated HCV/HIV coinfection, the main outcome variable of the study. All prevalence estimates reported are antibody prevalences.

Explanatory variables used in the analyses are shown in Table 1. These were based on self-reports and comprised socio-demographic, drug use, and higher-risk behavioral indicators recommended by the EMCDDA for monitoring drug-related infectious diseases at the national level $[49,50]$ and are supported by the relevant literature (reviewed in the Introduction [5, 28-39]).

\section{Statistical analysis}

Complete serological and behavioral data were collected for 545 treatment entrants (94.0\%). We were interested in identifying injection drug users at the greatest infection risk from their socio-demographic, drug use and higher-risk behavioral characteristics, as well as differentiating those at risk of $\mathrm{HCV}$ monoinfection from those at risk of $\mathrm{HCV} / \mathrm{HIV}$ coinfection. Multinomial logistic regression analyses were conducted to identify differences between different levels of infection status according to these characteristics. Three mutually exclusive groups of injection drug users were defined based on the presence of HCV and HIV antibodies. Group 1 clients had neither infection (uninfected, $n=111$ ), Group 2 had HCV but not HIV (HCV monoinfected, $n=349$ ), and Group 3 had HCV/HIV coinfection $(n=81)$. These groups formed the three levels of infection status. A fourth group - those with HIV but not HCV (HIV monoinfected) - consisted of only four persons and was excluded from the analyses. Also excluded were 35 cases with missing serological data in either $\operatorname{HCV}(n=17$, of whom 3 were HIV positive) or HIV ( $n=18$, of whom 17 were $\mathrm{HCV}$ positive) indicators. 
Table 1 Sample characteristics in total sample $(n=580)$ and in groups defined by HIV/HCV infection status $(n=541)^{\text {a }}$

\begin{tabular}{|c|c|c|c|c|}
\hline & $\begin{array}{l}\text { Total sample } \\
(n=580)\end{array}$ & $\begin{array}{l}\text { Uninfected }^{\mathrm{b}} \\
(n=111,20.4 \%)\end{array}$ & $\begin{array}{l}\text { HCV monoinfected }^{c} \\
(n=349,64.0 \%)\end{array}$ & $\begin{array}{l}\text { HCV/HIV coinfected } \\
(n=81,14.9 \%)\end{array}$ \\
\hline & $N(\%)^{\mathrm{e}}$ & $N(\%)$ & $N(\%)$ & $N(\%)$ \\
\hline Male (vs. Female) ${ }^{f}$ & $463(79.8)$ & 95 (85.6) & $272(77.9)$ & $67(82.7)$ \\
\hline Median age [Inter-quartile range] & $36[12]$ & $35[7]$ & $36[14]$ & $33[10]$ \\
\hline Greek nationality (vs. Non-Greek nationality) & $554(95.5)$ & $109(98.2)$ & $332(95.1)$ & $76(93.8)$ \\
\hline $\begin{array}{l}\text { Lived in urban area in the last } 5 \text { years (vs. Semi-urban/rural } \\
\text { area in the last } 5 \text { years) }\end{array}$ & $444(79.6)$ & $84(77.1)$ & $264(78.8)$ & $71(91.0)$ \\
\hline $\begin{array}{l}\text { Living alone or with spouse/partner without children } \\
\text { (vs. Living with family }{ }^{9} \text { ) }\end{array}$ & $182(31.9)$ & $23(20.7)$ & $120(34.4)$ & $30(37.0)$ \\
\hline $\begin{array}{l}\text { Homeless } \geq 1 \text { night in the past } 12 \text { months (vs. Never in the } \\
\text { past } 12 \text { months) }\end{array}$ & $186(32.6)$ & $26(23.4)$ & $107(31.2)$ & $42(53.2)$ \\
\hline $\begin{array}{l}\text { Did not graduate high school ( } 12^{\text {th }} \text { grade) (vs. Graduated } \\
\text { high school) }\end{array}$ & $360(62.1)$ & $61(55.5)$ & $215(62.0)$ & $59(74.7)$ \\
\hline $\begin{array}{l}\text { Employed (vs. Unemployed/student/other and economically } \\
\text { inactive }^{h} \text { ) }\end{array}$ & $137(23.7)$ & $32(28.8)$ & $88(25.4)$ & $9(11.1)$ \\
\hline Incarcerated at least once in lifetime (vs. Never) & $382(66.7)$ & $55(50.5)$ & $241(69.3)$ & $57(72.2)$ \\
\hline Use of primary substance $\geq 4$ days a week (vs. Less frequently) & $466(80.5)$ & $93(83.8)$ & $272(78.2)$ & $71(87.7)$ \\
\hline Use of $\geq 3$ substances of abuse (vs. $<3$ substances of abuse) & $367(63.3)$ & $66(59.5)$ & $219(62.8)$ & $53(65.4)$ \\
\hline Median length of injection (years) [Inter-quartile range] & $14[12]$ & $10[11]$ & $15[12]$ & $13[12]$ \\
\hline $\begin{array}{l}\text { Mean times of injection per day in the past } 30 \text { days [Standard } \\
\text { deviation] }\end{array}$ & $1.9[3.3]$ & $1.2[2.0]$ & $1.6[3.0]$ & $3.9[5.4]$ \\
\hline $\begin{array}{l}\text { Non-sterile syringe in last injection (vs. Sterile syringe in last } \\
\text { injection) }\end{array}$ & $45(8.1)$ & $5(4.8)$ & $25(7.5)$ & $10(12.7)$ \\
\hline $\begin{array}{l}\text { Shared syringes in the past } 12 \text { months (vs. No syringe sharing } \\
\text { in the past } 12 \text { months) }\end{array}$ & $137(25.4)$ & $16(15.1)$ & $75(23.1)$ & $33(44.6)$ \\
\hline $\begin{array}{l}\text { Shared other injection equipment in the past } 12 \text { months } \\
\text { (vs. Never in the past } 12 \text { months) }\end{array}$ & $237(43.7)$ & $42(40.4)$ & $131(40.3)$ & $44(57.1)$ \\
\hline $\begin{array}{l}\text { Two or more sexual partners in the past } 12 \text { months } \\
\text { (vs. }<2 \text { partners) }\end{array}$ & $211(36.6)$ & $42(38.9)$ & $120(34.5)$ & $35(43.2)$ \\
\hline $\begin{array}{l}\text { Sex in exchange for money etc. in the past } 12 \text { months } \\
\text { (vs. Never in the past } 12 \text { months/non-active) }\end{array}$ & $37(6.5)$ & $4(3.7)$ & $22(6.4)$ & $8(10.1)$ \\
\hline $\begin{array}{l}\text { No condom use in the last intercourse (vs. Use of condom } \\
\text { use or non-active) }\end{array}$ & $246(43.5)$ & $51(47.7)$ & $155(45.2)$ & $21(26.6)$ \\
\hline $\begin{array}{l}\text { Ever entered treatment for drug-related problems before } \\
\text { (vs. Never before) }\end{array}$ & $388(67.7)$ & $67(62.6)$ & $244(69.9)$ & $51(63.8)$ \\
\hline Never tested for HCV before (vs. Tested for HCV before) & $182(32.1)$ & $56(51.9)$ & $109(32.2)$ & $10(12.3)$ \\
\hline Never tested for HIV before (vs. Tested for HIV before) & $192(30.7)$ & $50(45.9)$ & $100(29.2)$ & $12(14.8)$ \\
\hline
\end{tabular}

${ }^{\mathrm{a} O S T}$ entrants with both statuses known, excluding four with HIV monoinfection. ${ }^{\mathrm{b}}$ Diagnosed HCV negative and HIV negative. ${ }^{\mathrm{c}}$ Diagnosed HCV positive and HIV negative. ${ }^{d}$ Diagnosed HCV positive and HIV positive. ${ }^{e}$ Where applicable, Median [Interquartile means] or Mean [Standard deviation]. ${ }^{f}$ Gender was measured by the following item: "What is your gender?" Response options included "male", "female", "other (transgender)". No person responded "other" in the sample used in the present analysis. ${ }^{9}$ Includes children and/or parents. "The category "economically inactive" includes the long-term sick, unpaid carers and persons living on pensions or benefits, but excludes students. 'Tobacco use was not measured. Possible abuse of alcohol or non-medical use of prescription drugs is included

Explanatory variables (all categorical) were first tested in univariate multinomial logistic regression analyses. Variables with $p<0.05$ and gender were included in the multivariable model. The final regression model included only the variables which were statistically significant $(p<0.10)$ in the multivariable model and was fitted to the data from 450 cases for which complete data were available. Likelihood ratio tests were carried out for the overall effect of an explanatory variable and Wald tests for the coefficients of individual categories against the reference category. Analyses were conducted using IBM SPSS Statistics for Windows, Version 22.0 (Armonk, NY: IBM Corp. IBM Corp. Released 2013). Relative risk ratios (RRR) and $95 \%$ confidence intervals (CI) are presented.

\section{Results}

Table 1 presents socio-demographic, behavioral and serological characteristics of the sample. The vast majority $(95.5 \%)$ were of Greek origin, males (79.8\%), with 
median age 36 years (quartiles: 31, 43) and median length of injection 14 years (quartiles: 8, 20).

HCV infection was detected in 447 (79.4\%) of 563 clients with reported HCV test results and HIV in 88 of 562 cases $(15.7 \%)$. The uninfected (Group 1) comprised $20.4 \%$ of those with complete serological data in both $\mathrm{HCV}$ and HIV indicators $(n=111), 64.0 \%$ were HCV monoinfected ( $n=349$, Group 2) and $14.9 \%(n=81)$ were $\mathrm{HCV} / \mathrm{HIV}$ coinfected (Group 3). Four people $(0.7 \%)$ were HIV monoinfected. The vast majority (95.3\%) of HIV infected people had HCV comorbidity. The HIV/HCV prevalence ratio (i.e., relative prevalence of HIV compared to HCV) was $19.8 \%$. The prevalence of HIV in HCV positive and HCV negative clients was 18.8 and $3.5 \%$, respectively $(p<0.001)$.

Among the correlates tested individually for their relation to the infection groups (univariate analyses) a number of factors showed positive association $(p<0.05)$ with infection status. These included: aged $\geq 35$ years, living in an urban area, living alone or with spouse / partner without children, having been homeless in the past 12 months, having not been graduated from high-school, not being employed, having been incarcerated, long injection history, frequent daily injection, and having shared injection equipment in the past 12 months. No condom use in the last intercourse, never having been tested for $\mathrm{HCV}$, and never having been tested for HIV showed negative association with infection status (Table 2).

The results of the multivariate analysis (final model comprising only the significant $-p<0.10$ - variables from the previous model) are shown in Table 3 . The probability of belonging to an infected group versus the uninfected group was positively related to living alone or with a spouse/partner without children $(p=0.007$, overall $p$-value for this covariate), incarceration $(p=0.018)$, having an injecting history of at least 10 years $(p=0.002)$, and having shared syringes in the past 12 months $(p=0.002)$. The risk of infection was reduced in injection drug users who reported that they had never previously been tested for HCV $(p=0.001)$.

Risk factors for $\mathrm{HCV} / \mathrm{HIV}$ coinfection, but not $\mathrm{HCV}$ monoinfection, were residence in major urban areas $(\mathrm{RRR}=4.8,95 \% \mathrm{CI}: 1.7-13.7, p=0.004)$ and averaging $>3$ injections a day in the last 30 days $(R R R=4.5$, CI: 1.6-12.8, $p=0.005)$. The risk of coinfection was reduced in injection drug users who did not use a condom in the last sexual intercourse (RRR $=0.4$, CI: $0.2-$ $0.9, p=0.018$ ).

Additional multivariate analyses, with the HCV monoinfected group as the reference category, showed that the risk of $\mathrm{HCV} / \mathrm{HIV}$ coinfection was higher among those living in urban areas (RRR $=3.4,95 \%$ CI: $1.3-8.7$, $p=0.012$ ), averaging $>3$ injections a day in the last 30 days $(\mathrm{RRR}=4.0, \mathrm{CI}: 2.0-8.2, \quad p<0.001)$, and lower among injection drug users who were aged $\geq 35$ years $(R R R=0.4$, CI: $0.2-0.7, p=0.004)$, did not use a condom in the last sexual intercourse (RRR $=0.5$, CI: $0.3-0.9, p=0.030$ ), and had never previously been tested for $\mathrm{HCV}(\mathrm{RRR}=0.4, \mathrm{CI}$ : $0.2-0.8, p=0.015)$ (data not shown in Table).

\section{Discussion}

Greece is a country with a high HIV and HCV epidemic among people who inject drugs $(41,46)$. In the present study we estimated the prevalence of HCV/HIV coinfection in a sample of injection drug users entering OST in Greece in 2013 to be 14.9 \%, with almost all HIV seropositive persons ( $95.3 \%$ ) having HCV comorbidity. We also aimed to identify injection drug users at the greatest risk of HCV/HIV coinfection on the basis of their sociodemographic, drug use and higher-risk behavioral characteristics. Our findings corroborate existing evidence suggesting that lengthy injecting careers, syringe sharing and prior incarceration independently increase the risk of infection. The present study additionally showed that the risk also increases in people who inject drugs and live alone or with a spouse/partner without children (as opposed to living with parents and /or children). Risk factors for HCV/HIV coinfection, but not HCV monoinfection, were residence in major urban areas and averaging more than 3 injections a day in the past 30 days.

Specifically, injection drug users with injecting histories of 10 or more years were at increased risk for both HCV monoinfection and HCV-HIV coinfection (almost six and fourteen times higher, respectively) compared to drug users with shorter injecting histories. Similarly, sharing a used syringe also increased the risk of infection, with those who reported syringe sharing in the 12 months preceding the treatment entry having almost five times greater risk of coinfection compared to those who had not shared in the past year. These findings are supported by ample evidence implicating long injecting histories and syringe sharing as key risk factors for coinfection [31-33, 35, 51]. There is also ample evidence suggesting that interventions that offer OST and HCV and HIV treatment to infected persons, coupled with needle and syringe programs (NSPs) and safer injecting rooms, may be vital in interrupting higher-risk injecting routines and reducing syringe sharing, thereby preventing new infections and reducing prevalence in this population (see [52] for review; also [53-60]). Harm reduction programs in Greece have generally had limited coverage [61, 62]. The 2011 HIV outbreak in injection drug users, coupled with international pressure and EU funding support, led to a public health response that focused on enforcement-based interventions covering diagnosis, scaling-up NSPs and OST, and linkage of HIV seropositives to ART (see e.g., [46]). Although restricted to Athens, interventions coincided with a significant 
Table 2 Results of univariate analysis of factors associated with HCV monoinfection and HCV/HIV coinfection

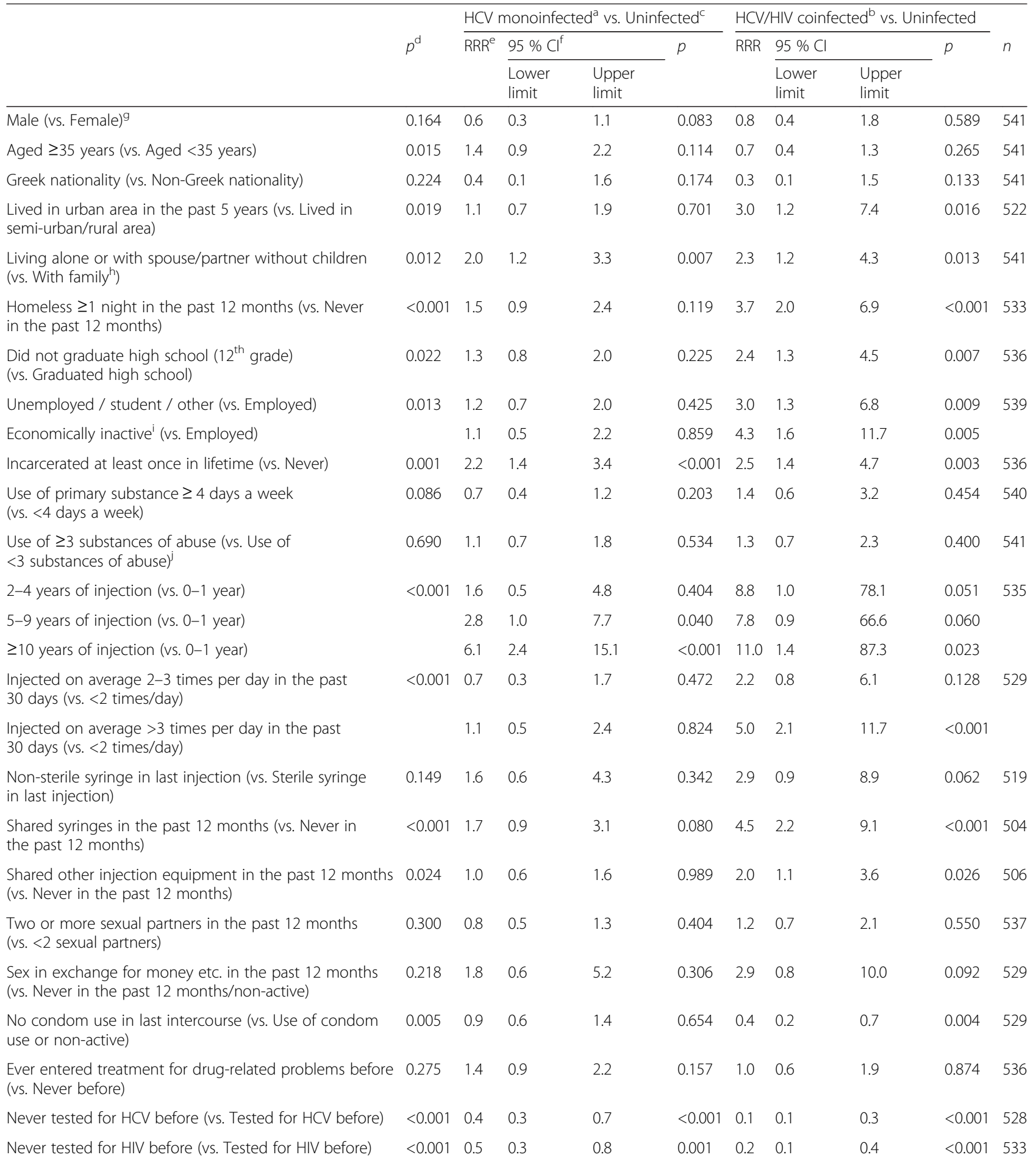

${ }^{a}$ Diagnosed HCV positive and HIV negative. ${ }^{b}$ Diagnosed HCV positive and HIV positive. ${ }^{\mathrm{c} D i a g n o s e d ~ H C V ~ n e g a t i v e ~ a n d ~ H I V ~ n e g a t i v e . ~}{ }^{\mathrm{d}}$ Overall $p$-value for this covariate. ${ }^{e}$ RRR: relative risk ratios. ${ }^{f} 95 \%$ confidence intervals. "Gender was measured by the following item: "What is your gender?" Response options included "male", "female", "other (transgender)". No person responded "other" in the sample used in the present analysis." Includes children and or parents. 'The category "economically inactive" includes the long-term sick, unpaid carers and persons living on pensions or benefits, but excludes students. In the present analysis, the status "student" was collapsed with the category "unemployed" under the assumption that, like people who are unemployed, students may be motivated to improve their physical and socioeconomic conditions and therefore are ready to undertake fewer health risks. ${ }^{j}$ Tobacco use was not measured. Possible abuse of alcohol or non-medical use of prescription drugs is included 
Table 3 Results of the multinomial logistic regression analysis of factors associated with HCV monoinfection and HCV/HIV coinfection (final model comprising only the significant $-p<0.10$ - variables from the previous model, $n=450$ )

\begin{tabular}{|c|c|c|c|c|c|c|c|c|c|}
\hline \multirow[t]{3}{*}{ Correlate (vs. Reference category) } & \multirow{3}{*}{$p^{d}$} & \multicolumn{4}{|c|}{ HCV monoinfected $^{a}$ vs. Uninfected ${ }^{c}$} & \multicolumn{3}{|c|}{$\begin{array}{l}\text { HCV/HIV coinfected }{ }^{b} \text { vs. } \\
\text { Uninfected }\end{array}$} & \multirow{3}{*}{$p$} \\
\hline & & \multirow[t]{2}{*}{$\overline{\mathrm{RRR}^{\mathrm{e}}}$} & \multicolumn{2}{|l|}{$95 \% \mathrm{Cl}^{f}$} & \multirow[t]{2}{*}{$p$} & \multirow[t]{2}{*}{$\overline{R R R}$} & \multicolumn{2}{|l|}{$95 \% \mathrm{Cl}$} & \\
\hline & & & Lower limit & Upper limit & & & Lower limit & Upper limit & \\
\hline Male (vs. Female) ${ }^{g}$ & 0.023 & 0.4 & 0.2 & 0.9 & 0.018 & 0.7 & 0.2 & 2.0 & 0.499 \\
\hline Aged $\geq 35$ years (vs. Aged <35 years) & 0.015 & 1.2 & 0.7 & 2.1 & 0.493 & 0.5 & 0.2 & 1.0 & 0.066 \\
\hline $\begin{array}{l}\text { Lived in urban area in the last } 5 \text { years (vs. Lived in } \\
\text { semi-urban/rural area) }\end{array}$ & 0.006 & 1.4 & 0.8 & 2.6 & 0.255 & 4.8 & 1.7 & 13.7 & 0.004 \\
\hline $\begin{array}{l}\text { Living alone or with a spouse/partner without children } \\
\text { (vs. With family }{ }^{h} \text { ) }\end{array}$ & 0.007 & 2.6 & 1.3 & 4.9 & 0.005 & 3.1 & 1.3 & 7.3 & 0.010 \\
\hline Incarcerated at least once in lifetime (vs. Never) & 0.018 & 2.0 & 1.2 & 3.4 & 0.008 & 2.5 & 1.1 & 5.3 & 0.021 \\
\hline 5-9 years of injection (vs. 0-1 year) & 0.002 & 2.4 & 0.8 & 7.2 & 0.134 & 6.0 & 0.6 & 60.6 & 0.129 \\
\hline 2-4 years of injection (vs. 0-1 year) & & 1.5 & 0.4 & 5.6 & 0.529 & 8.2 & 0.7 & 92.2 & 0.088 \\
\hline$\geq 10$ years of injection (vs. 0-1 year) & & 5.5 & 1.9 & 15.9 & 0.002 & 14.1 & 1.5 & 133.8 & 0.021 \\
\hline $\begin{array}{l}\text { Injected on average } 2-3 \text { times per day in the past } 30 \text { days } \\
\text { (vs. }<2 \text { times/day) }\end{array}$ & 0.003 & 1.1 & 0.3 & 3.4 & 0.916 & 2.6 & 0.6 & 10.5 & 0.186 \\
\hline $\begin{array}{l}\text { Injected on average }>3 \text { times per day in the past } 30 \text { days } \\
\text { (vs. }<2 \text { times/day) }\end{array}$ & & 1.1 & 0.4 & 2.9 & 0.805 & 4.5 & 1.6 & 12.8 & 0.005 \\
\hline $\begin{array}{l}\text { Shared syringes in the past } 12 \text { months (vs. No syringe } \\
\text { sharing in the past } 12 \text { months) }\end{array}$ & 0.002 & 2.5 & 1.2 & 5.2 & 0.014 & 4.7 & 1.9 & 11.5 & 0.001 \\
\hline $\begin{array}{l}\text { No condom use in last intercourse (vs. Use of condom } \\
\text { or non-active) }\end{array}$ & 0.043 & 0.8 & 0.5 & 1.4 & 0.424 & 0.4 & 0.2 & 0.9 & 0.018 \\
\hline Never tested for HCV before (vs. Tested for HCV before) & 0.001 & 0.6 & 0.3 & 0.9 & 0.028 & 0.2 & 0.1 & 0.5 & $<0.001$ \\
\hline
\end{tabular}

reduction of HIV incidence $[46,63]$. However, these programs have not proved financially sustainable [64]. Furthermore, under the austerity policies imposed from 2010 up to the present, public spending allotted to harm reduction has been minimal.

Living alone or only with a spouse/partner (without children or other family members, e.g., parents) trebled in our study the risk of $\mathrm{HCV}$ infection with or without HIV. Previous research has shown that higher-risk drug use is positively associated with intimacy among friendship networks [65]. At the same time, pockets of social support may reduce $\mathrm{HCV}$ and HIV related morbidity and mortality [66]. Taking care of children and living with a member of one's (biological) family is an often overlooked yet potentially important aspect of social support, especially in countries like Greece where the family retains its pivotal role in the lives of drug users [67]. The latter may influence health behaviors through self-regulation in conformity to norms or through others' health promoting behaviors and expectations [68]. In our study the likely absence of social support may have nurtured the adoption of risky behaviors in relation to HIV.

Our findings also suggest that those who have been incarcerated have twice as high a risk of $\mathrm{HCV}$ infection with or without HIV, suggesting that prison environments foster high-risk injection and sexual behavior and hence the acquisition of infection. The cross-sectional nature of our data does not allow us to make inferences about causality, but the independent association between incarceration and $\mathrm{HCV}, \mathrm{HIV}$, and $\mathrm{HCV} / \mathrm{HIV}$ coinfection in this population is well documented [51, 69]. In Greece, no administrative alternatives to imprisonment are implemented for drug users. As of 2016, prisoners in Greece do not have access to sterile injection equipment or condoms, while screening, HIV counseling, and ART are not routinely available [70]. Since 2015, OST and drug-related health care has been available in only two of the eighteen prison units in operation in the country. Furthermore, following incarceration, low coverage of services and other structural barriers (e.g., lack of essential documents, language restrictions, poverty, stigma or fear) may have promoted behaviors with higher health risk in this population.

$\mathrm{HCV} / \mathrm{HIV}$ coinfection (but not $\mathrm{HCV}$ monoinfection) was independently associated with frequent injection and residing in metropolitan areas. More specifically, living in an urban area and averaging more than 3 injections a day increased the risk by almost five. Living in an urban area represents a marker for high-risk factors. 
These factors include barriers in access to health services coupled with relatively easy access to multiple and novel substances of unknown composition and adverse effects, participation in larger, unknown and changing injection and sexual networks, and exposure to sex work (e.g. [5]). In addition, fear of arrest or punishment may displace or lead drug injectors to avoid using outreach programs, or to hurried injections and injection practices that increase opportunities for parenteral exposures to HIV.

Theoretically, having a test for infectious diseases is an indicator of health-protecting attitude [50], leading to the assumption that drug users who have been tested in the past will more likely be uninfected. Counterintuitively, our study showed that the risk of being infected was negatively associated with previous $\mathrm{HCV}$ testing. Unfortunately, the cross-sectional nature of the present study and the fact that we did not measure the time at which both the infection and previous testing occurred, or whether the test result was known to the participant, prevent us from being able to interpret these findings.

There was also a negative association between having used a condom in the last sexual intercourse and the risk of $\mathrm{HCV} / \mathrm{HIV}$ coinfection (but not of $\mathrm{HCV}$ monoinfection). Again, lack of additional data (e.g., frequency of sexual activity, partner's sexual orientation etc.) or more relevant variables (e.g., overall consistency of condom use) prevent us from fully explaining these findings. However, a number of hypotheses may be proposed: first, it may be that those who responded that they did use a condom in their last sexual intercourse had been prior to the last occasion- largely reckless in their sexual behavior. Second, the category included people who had no sex in the last 12 months, who possibly knew their positive serological status and abstained from sex. Third, the present data were collected in a period in which the HIV epidemic and the corresponding health-risk awareness and HIV counselling programs were at their greatest extent, reaching a substantial number of injection drug users (especially in Athens) [41, 46, 62]. Against this background it may be that those who reported that they did use a condom in the last sexual intercourse were giving the socially desired response. Finally, it may also be that those who responded that they did not use a condom in the last sexual intercourse were more cautious with other high-risk behaviors.

The findings of our study should be seen in the light of several limitations. First, the study participants were recruited only from OST outpatient clinics and only from central and southern Greece. In theory this affects the generalizability of our findings. However, clinics and participants in the present study comprised about $70 \%$ of national totals that year (2013). Second, we focused only on injection drug users and injection practices in general among heroin and other opioid users. Using stimulants (e.g., in the case of Greece, 'shisha', a variant of methamphetamine) also has destabilizing effects $[5,71]$. However, only a small proportion of study participants reported primary use of stimulants, including cocaine (2.4\%), and therefore this behavior was not included as a correlate in the analysis. Third, the cross-sectional design of the study does not allow the establishment of a causal relationship or a direction of causality between empirically related variables. Furthermore, as we did not measure whether HIV and HCV seropositives were known positives prior to the data collection, or whether they had already received specialised infectious diseases treatment, we could not check for possible interactions with other variables examined in the study. Finally, although data collection protocols have been employed for years in ways that elicit valid responses, possible misreporting associated with recall and social desirability biases [72] during the interview cannot be overlooked.

\section{Conclusions}

The positive association observed between infection and lengthy injection histories points to the need for scalingup OST programmes and retaining people in treatment. The positive association between HCV/HIV coinfection and, independently, frequent daily injection and living in urban areas suggests that more injection equipment, screening and brief advice are required in order to reach out to more injection drug users, especially in the inner city areas of all major cities in the country. Prior incarceration increases the risk of infection, and this alone highlights the need to provide routine testing and harm reduction services in all detention centres in the country. Importantly, keeping in contact with their family (i.e., parents and/or children) may reduce the risk of infection for people who inject drugs, and this element could guide counselling that takes place at the treatment centre level and relies on building up family support systems.

\footnotetext{
Acknowledgements

The Drug Related Infectious Diseases (DRID) Medical Doctors Group of the Greek Organisation Against Drugs (OKANA) consists of the following people: Konstantina Alexakou; Olga Anagnostou; Giorgos Androulakis; Emmanuel Chalkiadakis; Ioanna Detsi; Anastasia Drimousi; Dimitra Frontzou; Melpomeni Gargoulaki; Maria Iosifidou; Katerina Kaliva; Anna Katsilli; Stavroula Kollia; Maria Kollitsida; Argyrios Kotsalis; Spiroula Makristathi; Theodoros Papadopoulos; Eleftheria Petroulaki; Vasilis Pinakas; Michael Spirellis; Konstantinos Stamatopoulos; Victoria Stavridou; Yolanda-Irena StepenTopalidi; Christos Tanis; Anastasios Tsantilas; Panayiota Tsekoura; Efrosini Tsirogianni. The present study relies on data routinely collected in the context of the implementation of the nationwide epidemiological surveillance system pertaining to the characteristics of the persons entering drug-related treatment and testing for infectious diseases in Greece. The authors would like to acknowledge the significant role of OKANA, the OKANA Directors and especially the Heads and the personnel of the opioid substitution treatment clinics for collecting and making these data available to the Greek REITOX Focal Point of the European Monitoring Centre for Drugs and Drug Addiction. Dr. Evaggelos Kafetzopoulos is the present OKANA Director and Professor
} 
Melpomeni-Minerva (Meni) Malliori was the Director when the data for the present study were collected (2013).

\section{Funding}

The authors certify that no funding has been received for the conduct of this study and/or preparation of this manuscript.

\section{Availability of data and materials}

The data underlying the findings reported in the submitted manuscript cannot be deposited in a publicly accessible repository as there is no such provision in either the terms of reference agreed between the Greek REITOX Focal Point and the Greek Organisation Against Drugs (OKANA) or the Hellenic Data Protection Authority decision (Number: 2186, 1/11/2001). The data file used for the analysis is available to editors and peer reviewers if requested. After publication, authors can make the data available to any reader directly upon reasonable request.

\section{Authors' contributions}

The Group of Drug Related Infectious Diseases (DRID) medical doctors of OKANA were responsible for the acquisition of the data. AF and MT directed the data collection and management process. AF designed the study and wrote the manuscript. EK and AA prepared the data and conducted all statistical analyses. CR overviewed the statistical analyses and contributed substantially to the writing of the manuscript. MT and AK read and critically revising the paper. All authors reviewed the data, contributed to their interpretation, and approved the final manuscript.

\section{Competing interests}

The authors declare that they have no competing interests.

\section{Consent for publication}

Not applicable. The manuscript reports anonymous data; the manuscript does not include details relating to any individual person's or clinic's data.

\section{Ethics approval and consent to participate}

The collection and management of the data at the Focal Point was approved by the Hellenic Data Protection Authority (Decision number: 2186, 1/11/2001).

\section{Author details}

${ }^{1}$ Epidemiology Unit, Greek Reitox Focal Point of the EMCDDA, University Mental Health Research Institute, 2 Soranou tou Efesiou St., Athens 11527 Greece. ${ }^{2}$ Panteion University of Social and Political Sciences, 136, Leoforos A. Siggrou, Kallithea, Athens 17671, Greece. ${ }^{3}$ University Mental Health Research Institute, 2 Soranou tou Efesiou St., Athens 11527, Greece. ${ }^{4}$ Greek Organisation Against Drugs, Athens Greece, 21, Averof st., 10433 Athens, Greece.

\section{Received: 4 April 2016 Accepted: 15 August 2016}

\section{Published online: 25 August 2016}

\section{References}

1. Aceijas C, Rhodes T. Global estimates of prevalence of HCV infection among injecting drug users. Int J Drug Policy. 2007;18(5):352-8.

2. Hagan H, Thiede H, Des Jarlais DC. HIV/hepatitis C virus co-infection in drug users: risk behavior and prevention. AIDS. 2005;19 Suppl 3:S199-207.

3. Strader DB. Coinfection with HIV and hepatitis $C$ virus in injection drug users and minority populations. Clin Infect Dis. 2005:41 Suppl 1:S7-13.

4. Hope VD, Eramova I, Capurro D, Donoghoe MC. Prevalence and estimation of hepatitis $B$ and $C$ infections in the WHO European Region: a review of data focusing on the countries outside the European Union and the European Free Trade Association. Epidemiol Infect. 2013;FirstView:1-17.

5. Miller CL, Wood E, Spittal PM, Li K, Frankish JC, Braitstein P, Montaner JS, Schechter MT. The future face of coinfection: prevalence and incidence of HIV and hepatitis C virus coinfection among young injection drug users. J Acquir Immune Defic Syndr. 2004;36(2):743-9.

6. Rhodes T, Platt L, Judd A, Mikhailova LA, Sarang A, Wallis N, Alpatova T, Hickman M, Parry JV. Hepatitis C virus infection, HIV co-infection, and associated risk among injecting drug users in Togliatti, Russia. Int J STD AIDS. 2005;16(11):749-54.
7. Vickerman P, Martin NK, Roy A, Beattie T, Group EC, Des Jarlais D, Strathdee S, Wiessing L, Hickman M. Is the HCV-HIV co-infection prevalence amongst injecting drug users a marker for the level of sexual and injection related HIV transmission? Drug Alcohol Depend. 2013;132(1):172-81.

8. Alter MJ. Epidemiology of viral hepatitis and HIV co-infection. J Hepatol. 2006:44(1 Suppl):S6-9.

9. Lumbreras B, Jarrin I, del Amo J, Perez-Hoyos S, Muga R. Garcia-de la Hera M, Ferreros I, Sanvisens A, Hurtado I, Hernandez-Aguado I: Impact of hepatitis $C$ infection on long-term mortality of injecting drug users from 1990 to 2002: differences before and after HAART. AIDS. 2006;20(1):111-6.

10. Smit C, van den Berg C, Geskus R, Berkhout B, Coutinho R, Prins M. Risk of hepatitis-related mortality increased among hepatitis $C$ virus/HIV-coinfected drug users compared with drug users infected only with hepatitis $C$ virus: a 20-year prospective study. J Acquir Immune Defic Syndr. 2008;47(2):221-5.

11. Smith DJ, Combellick J, Jordan AE, Hagan H. Hepatitis C virus (HCV) disease progression in people who inject drugs (PWID): A systematic review and meta-analysis. Int J Drug Policy. 2015;26(10):911-21.

12. Di Martino V, Rufat $P$, Boyer N, Renard P, Degos F, Martinot-Peignoux M, Matheron S, Le Moing V, Vachon F, Degott $C$, et al. The influence of human immunodeficiency virus coinfection on chronic hepatitis $C$ in injection drug users: a long-term retrospective cohort study. Hepatology. 2001;34(6):1193-9.

13. Monto A, Currie S, Wright TL. Liver disease in injection drug users with hepatitis C, with and without HIV coinfection. J Addict Dis. 2008;27(2):49-59.

14. Sanvisens A, Fuster D, Serra I, Tor J, Tural C, Rey-Joly C, Muga R. Estimated liver fibrosis and its impact on all-cause mortality of HCV-monoinfected and HCV/HIV-coinfected drug users. Curr HIV Res. 2011;9(4):256-62.

15. Altice FL, Kamarulzaman A, Soriano W, Schechter M, Friedland GH. Treatment of medical, psychiatric, and substance-use comorbidities in people infected with HIV who use drugs. Lancet. 2010;376(9738):367-87.

16. Taylor LE, Swan T, Matthews GV. Management of Hepatitis C Virus/HIV Coinfection Among People Who Use Drugs in the Era of Direct-Acting Antiviral-Based Therapy. Clin Infect Dis. 2013;57 suppl 2:S118-24.

17. Khalsa JH, Kresina T, Sherman K, Vocci F. Medical management of HIVhepatitis $C$ virus coinfection in injection drug users. Clin Infect Dis. 2005:41 Suppl 1:S1-6.

18. Kresina TF, Bruce RD, Cargill VA, Cheever LW. Integrating care for hepatitis C virus (HCV) and primary care for HIV for injection drug users coinfected with HIV and HCV. Clin Infect Dis. 2005;41 Suppl 1:S83-8.

19. McCance-Katz EF. Treatment of opioid dependence and coinfection with HIV and hepatitis C virus in opioid-dependent patients: the importance of drug interactions between opioids and antiretroviral agents. Clin Infect Dis. 2005;41 Suppl 1:S89-95.

20. Baum MK, Jayaweera DT, Duan R, Sales S, Lai S, Rafie C, Regev A, Page JB, Berkman R, Campa A. Quality of life, symptomatology and healthcare utilization in HIV/HCV co-infected drug users in Miami. J Addict Dis. 2008:27(2):37-48

21. Scheft H, Fontenette DC. Psychiatric barriers to readiness for treatment for hepatitis C Virus (HCV) infection among injection drug users: clinical experience of an addiction psychiatrist in the HIV-HCV coinfection clinic of a public health hospital. Clin Infect Dis. 2005:40 Suppl 5:S292-6.

22. Graham CS, Wells A, Edwards EM, Herren T, Tumilty S, Stuver SO, Samet JH, Nunes D, Horsburgh Jr CR, Koziel MJ. Effect of exposure to injection drugs or alcohol on antigen-specific immune responses in HIV and hepatitis C virus coinfection. J Infect Dis. 2007;195(6):847-56.

23. Cescon A, Chan K, Raboud JM, Burchell AN, Forrest Jl, Klein MB, Loutfy MR, Machouf N, Montaner JS, Tsoukas C, et al. Significant differences in clinical outcomes between HIV-hepatitis C virus coinfected individuals with and without injection drug use history. AIDS. 2014;28(1):121-7.

24. Mehta SH, Thomas DL, Sulkowski MS, Safaein M, Vlahov D, Strathdee SA. A framework for understanding factors that affect access and utilization of treatment for hepatitis C virus infection among HCV-mono-infected and HIV/HCV-co-infected injection drug users. AIDS. 2005;19 Suppl 3:S179-89.

25. Rey D, Carrieri MP, Spire B, Loubiere S, Dellamonica P, Gallais H, Cassuto GP, Gastaut JA, Obadia Y. Factors associated with liver biopsy performance in HCV-HIV coinfected injecting drug users with HCV viremia: results from a five-year longitudinal assessment. J Urban Health. 2004;81(1):48-57.

26. Beyrer C, Malinowska-Sempruch K, Kamarulzaman A, Strathdee SA. 12 myths about HIV/AIDS and people who use drugs. Lancet. 2010;376(9737):208-11.

27. Graham CS. Hepatitis C and HIV Co-infection: Closing the Gaps. JAMA. 2015;313(12):1217-8 
28. Akselrod H, Grau LE, Barbour R, Heimer R. Seroprevalence of HIV, hepatitis B virus, and HCV among injection drug users in Connecticut: understanding infection and coinfection risks in a nonurban population. Am J Public Health. 2014;104(9):1713-21.

29. Fisher DG, Reynolds GL, Jaffe A, Perez MJ. Hepatitis and human immunodeficiency virus co-infection among injection drug users in Los Angeles County. California J Addict Dis. 2006;25(2):25-32.

30. Garten RJ, Zhang J, Lai S, Liu W, Chen J, Yu XF. Coinfection with HIV and hepatitis $C$ virus among injection drug users in southern China. Clin Infect Dis. 2005;41 Suppl 1:S18-24.

31. Del Fava E, Kasim A, Usman M, Shkedy Z, Hens N, Aerts M, Bollaerts K, Scalia Tomba G, Vickerman P, Sutton AJ. Joint modeling of HCV and HIV infections among injecting drug users in italy using repeated cross-sectional prevalence data. Stat Commun Infect Dis. 2011. http://dx.doi.org/10.2202/1948-4690.1009.

32. Solomon SS, Srikrishnan AK, Mehta SH, Vasudevan CK, Murugavel KG, Thamburaj E, Anand S, Kumar MS, Latkin C, Solomon S, et al. High prevalence of HIV, HIV/hepatitis C virus coinfection, and risk behaviors among injection drug users in Chennai, India: a cause for concern. J Acquir Immune Defic Syndr. 2008;49(3):327-32.

33. Marmor M, Des Jarlais DC, Cohen H, Friedman SR, Beatrice ST, Dubin N, el-Sadr W, Mildvan D, Yancovitz S, Mathur U, et al. Risk factors for infection with human immunodeficiency virus among intravenous drug abusers in New York City. AIDS. 1987;1(1):39-44.

34. Mathei C, Shkedy Z, Denis B, Kabali C, Aerts M, Molenberghs G, Van Damme $P$, Buntinx F. Evidence for a substantial role of sharing of injecting paraphernalia other than syringes/needles to the spread of hepatitis C among injecting drug users. J Viral Hepat. 2006;13(8):560-70.

35. Zocratto KB, Caiaffa WT, Proietti FA, Carneiro-Proietti AB, Mingoti SA, Ribeiro GJ. HCV and HIV infection and co-infection: injecting drug use and sexual behavior, AjUDE-Brasil I Project. Cad Saude Publica. 2006;22(4):839-48.

36. Dumchev KV, Soldyshev R, Qian HZ, Zezyulin OO, Chandler SD, Slobodyanyuk P, Moroz L, Schumacher JE. HIV and hepatitis C virus infections among hanka injection drug users in central Ukraine: a crosssectional survey. Harm Reduct J. 2009;6:23.

37. Bollepalli S, Mathieson K, Jasiurkowski B, Hillier A, Post J, Bhanu S, Martin D, Van Thiel DH, Nadir A. A comparison of risk factors for HCV-mono-infection, HIV-mono-infection, and HCV/HIV-co-infection in a community setting. Dig Dis Sci. 2008;53(2):517-21.

38. Bollepalli S, Mathieson K, Bay C, Hillier A, Post J, Van Thiel DH, Nadir A. Prevalence of risk factors for hepatitis C virus in HIV-infected and HIV/ hepatitis C virus-coinfected patients. Sex Transm Dis. 2007;34(6):367-70.

39. Hosseini M, SeyedAlinaghi S, Kheirandish P, Esmaeli Javid G, Shirzad H, Karami N, Jahani M, Seyed Ahmadian M, Payvarmehr F, Mohraz M, et al. Prevalence and correlates of co-infection with human immunodeficiency virus and hepatitis $C$ virus in male injection drug users in Iran. Arch Iran Med. 2010;13(4):318-23.

40. European Monitoring Centre for Drugs and Drug Addiction [EMCDDA]. European drug report: trends and developments. Luxembourg: Publications Office of the European Union; 2015.

41. University Mental Health Research Institute [UMHRI]. National Report to the EMCDDA: "Greece: New Developments, Trends". Athens: Greek Reitox Focal Point of the EMCDDA; 2014.

42. Hellenic Center for Disease Control and Prevention [HCDCP]. HIV/AIDS Surveillance Report in Greece, 31-12-2014 (Issue 29). Athens: Hellenic Center for Disease Control and Prevention; 2014.

43. Kokkevi A, Alevizou S, Arvanitis Y, Liappas J, Stefanis C. AIDS-related behavior and attitudes among i.v. drug users in Greece. Int J Addict. 1992;27(1):37-50.

44. Pharris A, Wiessing L, Sfetcu O, Hedrich D, Botescu A, Fotiou A, Nikolopoulos GK, Malliori M, Salminen M, Suk JE, et al. Human immunodeficiency virus in injecting drug users in Europe following a reported increase of cases in Greece and Romania, 2011. Euro Surveill. 2011;16(48). Available online: http://www.eurosurveillance.org/ViewArticle. aspx?Articleld=20032.

45. Paraskevis D, Nikolopoulos G, Tsiara C, Paraskeva D, Antoniadou A, Lazanas M, Gargalianos P, Psychogiou M, Malliori M, Kremastinou J et al. HIV-1 outbreak among injecting drug users in Greece, 2011: a preliminary report. Euro Surveill. 2011;16(36). Available online: http://www.eurosurveillance.org/ ViewArticle.aspx?Articleld=19962

46. Hatzakis A, Sypsa V, Paraskevis D, Nikolopoulos G, Tsiara C, Micha K, Panopoulos A, Malliori M, Psichogiou M, Pharris A, et al. Design and baseline findings of a large-scale rapid response to an HIV outbreak in people who inject drugs in Athens, Greece: the ARISTOTLE programme. Addiction. 2015;110(9):1453-67.

47. Sypsa V, Paraskevis D, Malliori M, Nikolopoulos GK, Panopoulos A, Kantzanou M, Katsoulidou A, Psichogiou M, Fotiou A, Pharris A, et al. Homelessness and other risk factors for HIV infection in the current outbreak among injection drug users in Athens, Greece. Am J Public Health. 2015;105(1):196-204.

48. Malliori M, Sypsa V, Psichogiou M, Touloumi G, Skoutelis A, Tassopoulos N, Hatzakis A, Stefanis C. A survey of bloodborne viruses and associated risk behaviours in Greek prisons. Addiction. 1998;93(2):243-51.

49. Simon R, Donmall M, Hartnoll R, Kokkevi A, Ouwehand AW, Stauffacher M, Vicente J. The EMCDDA/Pompidou Group treatment demand indicator protocol: a European core item set for treatment monitoring and reporting. Eur Addict Res. 1999;5(4):197-207.

50. European Monitoring Centre for Drugs and Drug Addiction [EMCDDA]. DRID Guidance Module: behavioural indicators for people who inject drugs. Lisbon: EMCDDA; 2013.

51. Yen YF, Yen MY, Su LW, Li LH, Chuang P, Jiang XR, Deng CY. Prevalences and associated risk factors of HCV/HIV co-infection and HCV mono-infection among injecting drug users in a methadone maintenance treatment program in Taipei, Taiwan. BMC Public Health. 2012;12:1066.

52. Hagan $H$, Pouget ER, Des Jarlais DC. A systematic review and meta-analysis of interventions to prevent hepatitis $C$ virus infection in people who inject drugs. J Infect Dis. 2011;204(1):74-83.

53. Wodak A, Cooney A. Do needle syringe programs reduce HIV infection among injecting drug users: a comprehensive review of the international evidence. Subst Use Misuse. 2006;41(6-7):777-813.

54. Des Jarlais DC, Marmor M, Paone D, Titus S, Shi Q, Perlis T, Jose B, Friedman SR. HIV incidence among injecting drug users in New York City syringeexchange programmes. Lancet. 1996;348(9033):987-91.

55. Hurley SF, Jolley DJ, Kaldor JM. Effectiveness of needle-exchange programmes for prevention of HIV infection. Lancet. 1997;349(9068):1797-800.

56. Gibson DR, Brand R, Anderson K, Kahn JG, Perales D, Guydish J. Two- to sixfold decreased odds of HIV risk behavior associated with use of syringe exchange. J Acquir Immune Defic Syndr. 2002;31(2):237-42.

57. Des Jarlais DC, Hagan H, Friedman SR, Friedmann P, Goldberg D, Frischer M, Green S, Tunving K, Ljungberg B, Wodak A, et al. Maintaining low HIV seroprevalence in populations of injecting drug users. JAMA. 1995;274(15): 1226-31.

58. Strathdee SA, van Ameijden EJ, Mesquita F, Wodak A, Rana S, Vlahov D. Can HIV epidemics among injection drug users be prevented? AIDS. 1998; 12(Suppl A):S71-9.

59. MacDonald M, Law M, Kaldor J, Hales JJ, Dore G. Effectiveness of needle and syringe programmes for preventing HIV transmission. Int J Drug Policy. 2003;14(5):353-7.

60. WHO. Effectiveness of Sterile Needle and Syringe Programming in Reducing HIV/AIDS Among Injecting Drug Users. Evidence for Action. Technical Paper. Geneva: WHO; 2004

61. Hedrich D, Kalamara E, Sfetcu O, Pharris A, Noor A, Wiessing L, Hope V, Van de Laar M. Human immunodeficiency virus among people who inject drugs: Is risk increasing in Europe? Euro Surveill. 2013;18(48):20648.

62. Terzidou M, Fotiou A. Explosion de VIH chez les consommateurs de drogues en Grèce pendant la crise économique [HIV outbreak among people who inject drugs in Greece during the economic crisis]. SWAPS 2015;78:19-23.

63. Nikolopoulos GK, Sypsa V, Bonovas S, Paraskevis D, Malliori-Minerva M, Hatzakis A, Friedman SR. Big Events in Greece and HIV infection among people who inject drugs. Subst Use Misuse. 2015;50(7):1-14.

64. Nikolopoulos GK, Fotiou A. "Integrated interventions are dead. Long live sustainable integrated interventions!"- -Austerity Challenges the Continuation of Effective Interventions in the Field of Drug Use-Related Harm Reduction. Subst Use Misuse. 2015;50(8-9):1220-2.

65. Friedman SR, Aral S. Social networks, risk-potential networks, health, and disease. J Urban Health. 2001;78(3):411-8.

66. Uchino BN. Social support and health: a review of physiological processes potentially underlying links to disease outcomes. J Behav Med. 2006;29(4):377-87.

67. Fotopoulou M. Reasons behind Greek problem drug users' decisions to quit using drugs and engage in treatment of their own volition: sense of self and the Greek filotimo. Addiction. 2014;109(4):627-34.

68. Lloyd JJ, Ricketts EP, Strathdee SA, Cornelius LJ, Bishai D, Huettner S, Havens JR, Latkin C. Social contextual factors associated with entry into opiate 
agonist treatment among injection drug users. Am J Drug Alcohol Abuse. 2005;31(4):555-70.

69. Burris S, Chiu J. Punitive Drug Law and the Risk Environment for Injecting Drug Users: Understanding the Connections. In: Working paper prepared for the Third Meeting of the Technical Advisory Group of the Global Commission on HIV and the Law, 7-9 July 2011. 2011.

70. Zurhold H, Stöver H. Inventory of harm reduction measures in European prisons. Frankfurt: Frankfurt University of Applied Sciences; 2013.

71. Degenhardt L, Mathers B, Guarinieri M, Panda S, Phillips B, Strathdee SA, Tyndall M, Wiessing L, Wodak A, Howard J. Meth/amphetamine use and associated HIV: implications for global policy and public health. Int J Drug Policy. 2010;21(5):347-58.

72. Johnson T, Fendrich M. Modeling sources of self-report bias in a survey of drug use epidemiology. Ann Epidemiol. 2005;15(5):381-9.

Submit your next manuscript to BioMed Central and we will help you at every step:

- We accept pre-submission inquiries

- Our selector tool helps you to find the most relevant journal

- We provide round the clock customer support

- Convenient online submission

- Thorough peer review

- Inclusion in PubMed and all major indexing services

- Maximum visibility for your research

Submit your manuscript at www.biomedcentral.com/submit
) Biomed Central 